\title{
Embedding bullying related learning in the curriculum for initial teacher education: a possible approach
}

\author{
Daniela Maria Cretu, ${ }^{1, *}$ \\ 1 "Lucian Blaga" University of Sibiu, Teacher Education Department, 34 Calea Dumbrăvii 550324 \\ Sibiu, Romania
}

\begin{abstract}
Teachers are key players in preventing and combating the phenomenon of bullying in schools. To actively and constructively assume this role, they need bullying training during their initial and continuous teacher education. This study explores opportunities to engage pre-service teachers in learning about school bullying within the curriculum for initial teacher education in Romania. More competencies were identified as necessary for future teachers for being able to manage the problems related to bullying in school. Suggestions for bullying-related learning activities within the curriculum of four psycho-pedagogical disciplines are provided from the perspective of an infusion approach. This study can help or inspire other teacher educators' efforts to provide future teachers with the knowledge, skills, and attitudes they will need to tackle bullying situations in the school environment.
\end{abstract}

\section{Introduction}

Schools should provide physically and emotionally safe learning environments for all students, in which they can develop harmoniously under the guidance of teachers and the entire staff. However, the reality is not always like that. School is also the place where violence can manifest itself in various forms. One form of violence encountered in school is bullying among students. Bullying has three characteristics: it is an intentional harm-doing behaviour, it is conducted repeatedly and over time, it happens within a relationship characterized by an imbalance of power [1]. Taking many forms, such as physical (pushing, hitting, kicking), verbal (name-calling, yelling, insulting, threatening), social (social exclusion, spreading gossip or lies) and cyber (sending or posting hurtful text or images through digital devices), school bullying can affect the mental and physical health, the academic performance of children and young people and may lead to early school abandoning [2]. The students that were frequently exposed to bullying also felt sad, scared and less satisfied with their lives than students who were not exposed to the phenomenon [3].

Bullying is a reality of educational contexts in many countries, including Romania. According to a national survey, $73 \%$ of secondary school-age Romanian students

* Corresponding author: daniela.cretu@ulbsibiu.ro 
encountered a situation of peer bullying at the level of the school where they study, and $58 \%$ in the case of their class [4]. The same study indicates that while some teachers are more involved in stopping violent behaviour, others remain passive [4]. In addition, international reports show that Romania is among the countries where students' exposure to school bullying is high. For example, a 2018 international study shows that $34 \%$ of 15 year-old students in Romania reported being bullied at least a few times a month [3]. Another international report which used data from 24 countries in Asia, Europe, and Latin America indicated verbal bullying as the most frequent type of aggression in schools, but also the presence of actions undertaken by principals and teachers against bullying [5]. The TALIS report results show that bullying among students occurs at least once per week in $14 \%$ of schools, on average across OECD countries [6].

The devastating consequences of this phenomenon on the lives of children and youth, but also on the school and community in general, require firm measures to prevent and combat the phenomenon. Interventions in the whole school system, curriculum, teacher training, parental and community involvement, and appeals to different levels of national decision-makers are seen as necessary to address the school bullying [2]. As a result of the various measures applied, some countries have managed to reduce the incidence of bullying in schools, while others face an increase in the phenomenon [6].

Several studies that have addressed the issue of bullying or cyberbullying from the perspective of future teachers, highlighted the need for more training for pre-service teachers in universities on bullying [7-10] and on cyberbullying [11-13]. A poor and inadequate pre-service teacher training on bullying was reported $[9,14]$. However, few studies address how pre-service teachers could be prepared to deal with bullying in school contexts. Beran [7] suggested the inclusion of material on the topic of bullying in the university curriculum. Some authors consider that training could include discussions about bullying, examples of intervention toward the bullies and victims, or specific cases when students with special education needs are involved in bullying episodes [8]. In a study from Spain, the pre-service students reported a deeper understanding of the problem due to their enrolment in an elective course on bullying at university [9]. Another study provided an online project as an opportunity for pre-service teachers to develop awareness and confidence in identifying, managing, and preventing cyber-bullying [12]. There are differences between countries regarding the extent to which bullying is incorporated into pre-service teacher training [15]. Regardless of the nature of the approaches, bullying is a relevant topic for pre-service teacher's professional future.

This study explores opportunities to engage pre-service teachers in learning about school bullying within the current curriculum for initial teacher training in Romania. For this an infusion approach was developed, which is one of the models for integrating crosscurricular themes into the curriculum [16]. Bullying is a cross-curricular theme, which can be integrated in more disciplines within the initial teacher education. In this regard, some ideas were generated for embedding bullying-related learning activities within the existing discipline subject curriculum.

Selecting engaging activities related to certain topics, injection of the activities into the program, and providing support and encouragement for individuals and groups that want to expand activities are parts of an infusion-based approach [17]. In this study, only the first stage of this approach is presented, by suggesting bullying related learning activities in the context of the existing curriculum. These learning activities can support the pre-service teacher's involvement and intend to develop their knowledge, skills, and attitudes for addressing bullying. 


\section{The context of the study}

Legislative measures for bullying and violence prevention in schools have recently been published in Romania. The Romanian Ministry of Education and Research has developed the methodological guidelines to prevent and combat all forms of bullying in the preuniversity education system [18]. This document sets out specific actions that schools should follow in addressing cases. Legislation requires the educational institutions to develop strategies and plans to ensure and maintain a school climate suitable for quality education. Teachers are seen as key players in school-level anti-bullying action groups and this requires continuous teacher training on the topic [18]. Initial teacher training can be helpful as well by providing pre-service teachers with opportunities to learn about such a complex issue.

The Romanian curriculum for initial teacher education is structured on three components: the core curriculum, extended curriculum and optional curriculum. In this study, we will focus on learning opportunities related to the bullying issue identified within the psycho-pedagogical disciplines that are part of the core curriculum. More precisely, we refer to four disciplines, namely Educational Psychology, Pedagogy I (Fundamentals of Pedagogy; Theory and methodology of the curriculum), Pedagogy II (Theory and methodology of instruction and evaluation), Student Classroom Management. Through their contents, these disciplines offer more opportunities for social and emotional learning, which can support the personal and professional development of future teachers to face the reality of bullying in schools. The perspective of this study is based on the fact that teacher educators may help pre-service teachers to tackle the phenomenon by embedding bullying related content and learning activities in the existing core curriculum.

The research questions for this study were:

1. What competencies do pre-service teachers need to develop to deal with bullying in school?

2. What are the areas in the syllabus of psycho-pedagogical disciplines in which learning about bullying is present and where can it be developed?

\section{Methods}

Based on the analysis of the international specialized literature and of the Romanian legislative measures regarding school bullying, more competencies for future teachers were identified as necessary for being able to manage the problems related to bullying in school. Then, a content analysis of the syllabi associated with the psycho-pedagogical disciplines was performed to discover how the bullying theme is reflected in the initial training program for the teaching profession, but also to identify what possibilities for curriculum development exist within these disciplines.

Through an online questionnaire, eight teacher educators involved in initial teacher training at a university in Romania were consulted on the possibilities offered by their disciplines to address issues related to bullying. Suggestions for learning activities that can support the training of skills of future teachers in connection with the phenomenon of bullying have been collected. These suggestions were reformulated under the umbrella of the framework for rigor and relevance developed by the International Center for Leadership in Education [19]. They are organized according to the disciplines in tables and connected to the existent contents in the syllabi. 


\section{Results}

To answer the first research question, we define bullying-related competencies as a combination of knowledge, skills and attitudes needed by pre-service teachers to understand and recognize the phenomenon in the school environment, to prevent and combat it. The knowledge refers to the characteristics of bullying, types of bullying, identification of its causes and consequences, etc. In terms of abilities, active listening, assertive communication, observation of students' behaviors, adequate intervention, collaboration and communication with other factors involved in the management of the phenomenon etc. were identified as addressable. The attitudes integrate elements related to empathy, respect, solidarity, inclusion, willingness to communicate and cooperate, responsibility in the management of bullying cases, etc.

By integrating these elements, a set composed of three competencies was outlined: (1) preventing bullying behaviors in the school environment; (2) identifying different forms of bullying, risk factors and consequences; (3) combating school bullying by following the legislation. A similar framework with three categories, namely identification, management, and prevention was developed to guide researchers and educators in exploring cyberbullying with pre-service teachers [12]. This set of competencies is not designed in an all-inclusive regime, but rather is elaborated from the perspective of the necessity to be developed, revised or updated through continuous professional development (through courses, workshops, conferences, etc.). We do not rule out the possibility that other relevant elements in terms of knowledge, skills, or attitudes may complete the profile proposed in this paper. These competencies can guide the teacher educators in their effort to support the pre-service teachers to deal with school bullying and can build bridges between psychopedagogy disciplines. Each of the four disciplines from the core curriculum can contribute to these competencies through bullying-related learning activities (Fig. 1). The joint investment, through several disciplines, in these competencies increases the chances for the pre-service teacher to be prepared to tackle bullying in educational settings.

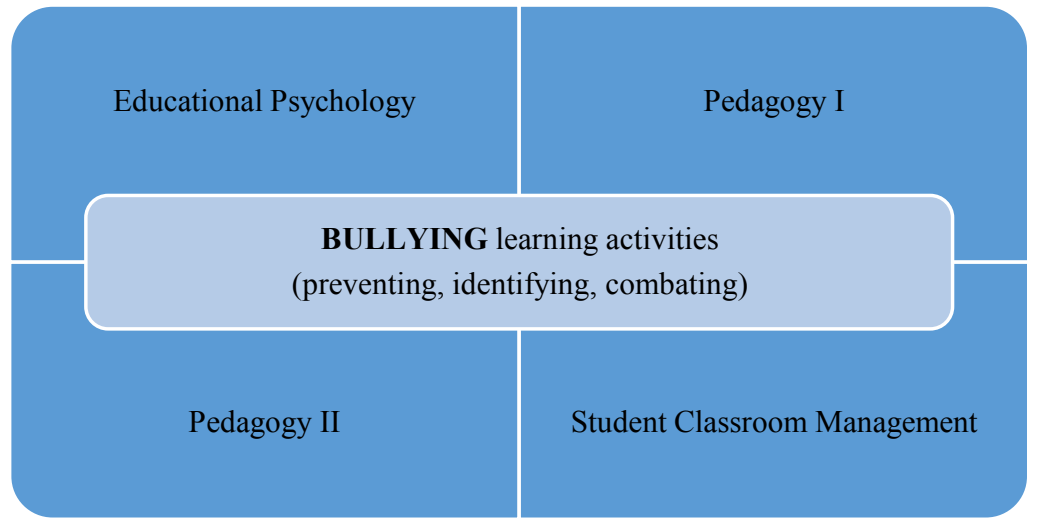

Fig. 1. Bullying infusion approach

To answer the second research question, two sources were used: the analysis of the psycho-pedagogical disciplines syllabi and the consultation of eight teacher educators through an online questionnaire. Regarding the first source, we mention that each discipline lasts one term, with a total number of course hours and seminars between 28 and $56 \mathrm{~h}$. These disciplines are sequenced over the three years of study within the program. Analysis of the syllabus in the four psycho-pedagogical disciplines showed that there are no formal 
learning outcomes in any course regarding the bullying. Little instruction on the topic is available from these documents.

The first and most obvious contact of pre-service teachers with bullying is found in the discipline of Educational Psychology, which explicitly addresses the issue of school violence (typology and methods of prevention) in two hours of course and as many hours of seminar. As bullying is a form of school violence, we find here an excellent opportunity to address issues related to this phenomenon, but with such little time it is not possible to generate solid knowledge, skills and attitudes for future teachers. In the syllabi of the other three disciplines, no explicit contents on this topic were identified. Instead, we identified contents that, by their nature, present possibilities for learning situations correlated with the bullying phenomenon, in terms of preventing, identifying or even combating it.

The teacher educators involved in teaching psycho-pedagogical disciplines were asked about the potential of the disciplines they teach for an infusion approach related to bullying. They expressed their opinions through an online questionnaire. They all agreed that the initial training program should equip teachers with knowledge and skills related to school bullying. In addition, all of them argued that it is possible to capitalize on the content of the subjects they teach for developing bullying-related learning activities. More precisely, the teacher educators identified contents within the syllabi that would allow them to embed learning activities related to bullying. Some of them suggested possible learning activities in relation to these selected contents.

The learning activities have been enriched and diversified from the perspective of the framework for rigor and relevance [19]. Thus, to foster rigor, learning activities were proposed, which can not only emphasize the acquisition of knowledge about bullying and understanding the phenomena, but also include case analysis, problem solving and generating solutions. To increase the relevance, learning activities that would allow the use of knowledge to address real-school bullying problems and cases were suggested. This rigor and relevance framework also guided the design of learning experiences for future teachers in another study [20].

Next, we provide a range of possible learning activities, which could be implemented with pre-service teachers in the four disciplines by teacher educators (Tables 1-3). Learning activities were conceived in relation within the existing content of these disciplines. The activities can be done during classes and seminars (in-class), but can also turn into ideas for homework, projects that pre-service teachers can do outside class (extended learning). The migration of these activities from one category to another is not excluded. Some activities can be done frontally (through debates, demonstrations, material viewings, brainstorming, etc.), in pairs or group work (think/pair/share, three-steps interviews, value line, group debates, jigsaw, etc.), while others are more appropriate for an individual work regime (reflections, elaboration of collages, documentaries, etc.). Teacher educators can choose from these activities or can develop others starting from those presented here. They can also decide how to embed them into their teaching practice.

Table 1. Suggestions of learning activities for pre-service teachers in the discipline of Educational Psychology

\begin{tabular}{|c|l|l|}
\hline Content & \multicolumn{1}{|c|}{ In-class learning activities } & \multicolumn{1}{c|}{ Extended learning } \\
\hline School violence & $-\begin{array}{l}\text { Reading and analysis of the Romanian legislation } \\
\text { regarding school bullying }\end{array}$ & $-\begin{array}{l}\text { Interview with a } \\
\text { student who witnessed }\end{array}$ \\
& $-\begin{array}{l}\text { Creating a dictionary with terms used in the } \\
\text { context of the bullying phenomenon }\end{array}$ & $\begin{array}{l}\text { a bullying incident at } \\
\text { school }\end{array}$ \\
& $-\begin{array}{l}\text { Debates on the role of teachers in identifying, } \\
\text { reporting, managing situations of school bullying }\end{array}$ & $\begin{array}{l}\text { Interview with a } \\
\text { teacher/school }\end{array}$ \\
& $-\begin{array}{l}\text { Analysis of scenarios or watching videos that } \\
\text { illustrate episodes of school bullying to identify }\end{array}$ & $\begin{array}{l}\text { counselor/parent about } \\
\text { a bullying situation }\end{array}$ \\
\hline
\end{tabular}




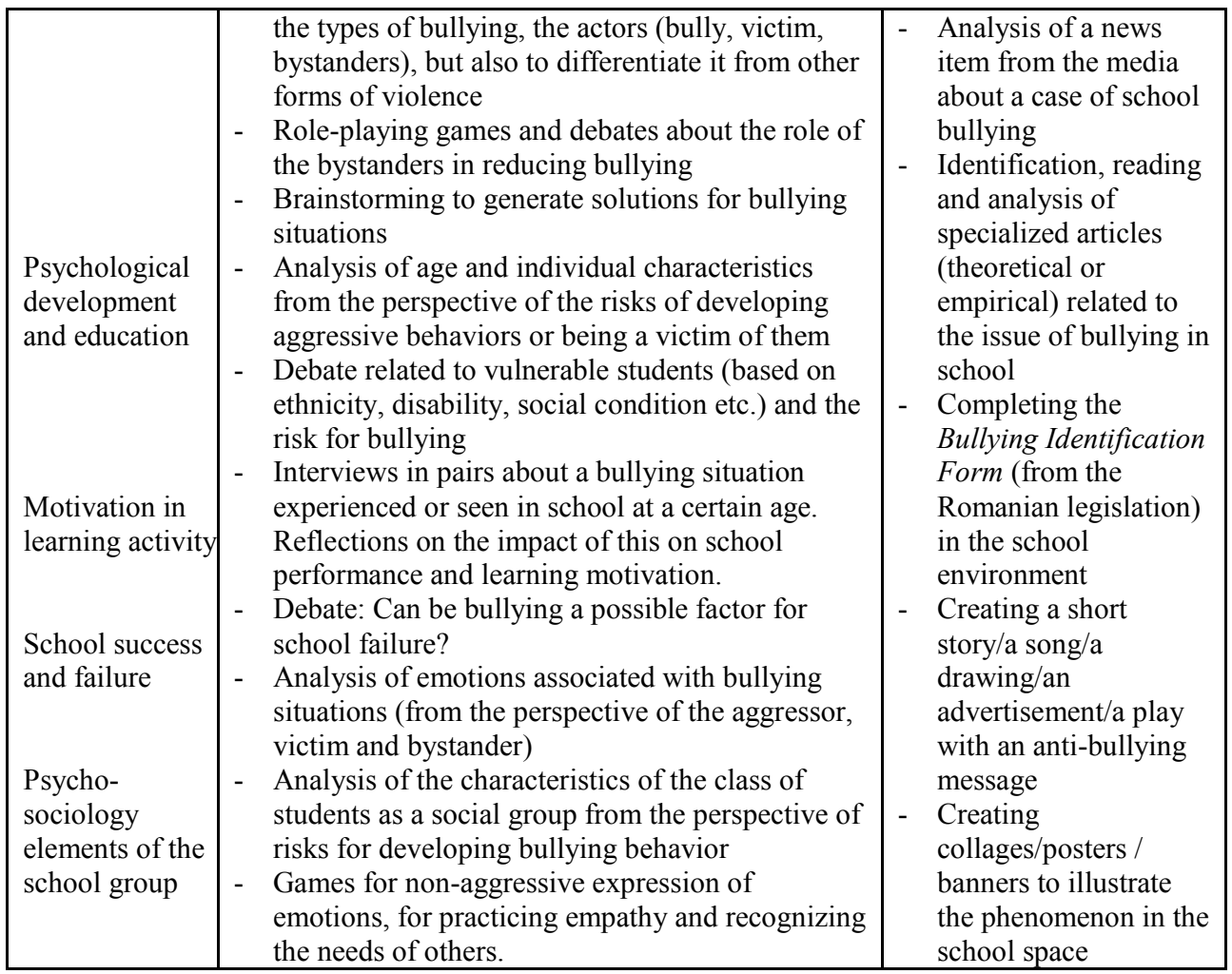

Table 2. Suggestions of learning activities within the Pedagogy I and Pedagogy II disciplines

\begin{tabular}{|c|c|c|}
\hline Content & In-class learning activities & Extended learning \\
\hline $\begin{array}{l}\text { Pedagogy I } \\
\text { Education in } \\
\text { contemporary } \\
\text { society } \\
\text { Moral } \\
\text { education }\end{array}$ & $\begin{array}{l}\text { - Reading, analysis and debating of national and } \\
\text { international reports in which the phenomenon } \\
\text { of bullying is presented in different educational } \\
\text { environments } \\
\text { - Exploring the potential of some methods of } \\
\text { moral education (conversation, moral example, } \\
\text { exercise, etc.) for school bullying situations (real } \\
\text { or fictitious) } \\
\text { - Debates on moral dilemmas of bullying or } \\
\text { cyber-bullying (from the perspective of the } \\
\text { bullies, bystanders and victims) } \\
\text { - Analysis of curricular documents (subject areas } \\
\text { in course syllabus, textbooks) from the } \\
\text { perspective of identifying and capitalizing on } \\
\text { topics relevant to the issue of bullying }\end{array}$ & $\begin{array}{l}\text { Pedagogical reading on } \\
\text { bullying, followed by } \\
\text { presentations, debates, } \\
\text { reflections of how } \\
\text { these inform the future } \\
\text { teachers } \\
\text { - Identification and } \\
\text { analysis of educational } \\
\text { research on the issue of } \\
\text { bullying } \\
\text { - Reading fiction books } \\
\text { on school bullying } \\
\text { followed by debates } \\
\text { (e.g. Miracle, by R.J. } \\
\text { Palacio; The Hundred }\end{array}$ \\
\hline $\begin{array}{l}\text { Pedagogy II } \\
\text { Teaching } \\
\text { methods } \\
\text { Cooperative } \\
\text { learning }\end{array}$ & $\begin{array}{l}\text { - Reflection on teaching methods and materials } \\
\text { which can be used to teach students about } \\
\text { bullying } \\
\text { - Implementation of cooperative learning methods } \\
\text { (group discussions, jigsaw, tour gallery, value } \\
\text { line, etc.) followed by reflections on } \\
\text { the integration of all students } \\
\text { - Practicing active listening through role-playing } \\
\text { games in various situations such as teacher- } \\
\text { student, student-student, teacher-parent }\end{array}$ & $\begin{array}{l}\text { Dresses, by E. Estes; } \\
\text { Dear bully, by M. K. } \\
\text { Hall, C. Jones) } \\
\text { - Browsing websites on } \\
\text { bullying subject } \\
\text { followed by } \\
\text { discussions with } \\
\text { colleagues } \\
\text { - Watching movies or } \\
\text { documentaries that } \\
\end{array}$ \\
\hline
\end{tabular}




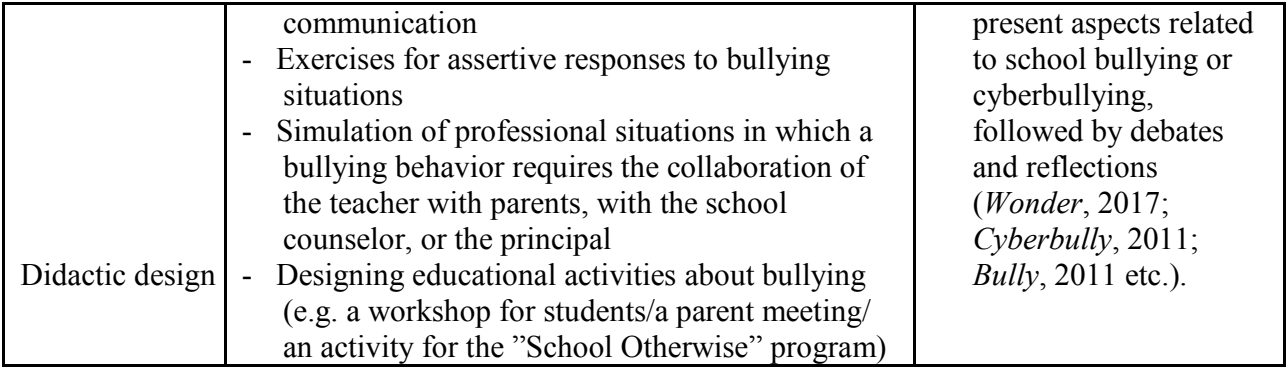

Table 3. Suggestions of learning activities for the discipline Student Classroom Management

\begin{tabular}{|c|c|c|}
\hline Content & In-class learning activities & Extended learning \\
\hline $\begin{array}{l}\text { Organizational } \\
\text { climate in the } \\
\text { student class }\end{array}$ & $\begin{array}{l}\text { - Generating word clouds (by using Wordle, } \\
\text { WordArt, Mentimeter, etc.) based on } \\
\text { brainstorming about "Scholl with bullying" and } \\
\text { "Scholl without bullying" followed by } \\
\text { discussions } \\
\text { - Analyze the intervention mechanism in } \\
\text { preventing and combating school bullying } \\
\text { - Simulation of intervention in an anti-bullying } \\
\text { action group at school level } \\
\text { - Engaging pre-service teachers in } \\
\text { establishing rules, rewards and consequences at } \\
\text { class level } \\
\text { - Scenarios and role-plays for conflict resolution } \\
\text { skills } \\
\text { - Discussion on students' diversity in the } \\
\text { classrooms and importance of nondiscriminatory } \\
\text { behavior of the teachers. }\end{array}$ & $\begin{array}{l}\text { Interviews with } \\
\text { principals or teachers } \\
\text { on the management of } \\
\text { the bullying cases in a } \\
\text { particular school } \\
\text { - Case studies on how } \\
\text { mechanisms for } \\
\text { preventing, identifying } \\
\text { and combating bullying } \\
\text { work at the level of a } \\
\text { school } \\
\text { - Designing a school- } \\
\text { level action } \\
\text { plan/campaign/ video } \\
\text { to prevent and combat } \\
\text { bullying }\end{array}$ \\
\hline
\end{tabular}

By providing an infusion instruction on the subject of school bullying through well and carefully designed learning activities, over three years, through various disciplines, the preservice teacher could be better prepared to deal with the phenomenon when they meet it in schools. They will recognize it, be able to use the skills and attitudes learned, taking action together with other human resources in schools. Some authors consider that the training of the pre-service teacher regarding the bullying phenomenon can support a "smooth transition into early career teaching and the success of schools' anti-bullying initiatives" [21]. In addition, they can embed bullying prevention messages in the school curriculum by lessons and activities [22]. If we consider what initial teacher education might do in relation to bullying we find that the possibilities are very diverse much increased. Other disciplines present the potential for designing and implementing bullying related learning activities for future teachers, too. The infusion approach can be extended to didactics of the specialized discipline and pedagogical practicum, which are also part of the core curriculum. For example, the direct contact of pre-service teachers with school reality through pedagogical practicum greatly increases the possibilities they have in terms of observing the bullying phenomenon in the school environment (its types, places where it happens, frequency, actors, interventions etc.). Completing the bullying identification form in the school environment, presenting the data collected, interviews with teachers or with students on this topic could be possible activities to incorporate in practicum. The materials developed by the pre-service teacher could be included in the practice portfolio or in the graduation portfolio of this training program. Then, the discipline Computer-assisted instruction (which is also part of the core curriculum) allows the approach of some essential activities related to how to stay safe online and how to report cyberbullying. When considering the 
engagement of young people in bullying behaviors in the online environment, special attention must be given to cyberbullying, and consequently to adequate training for preservice teachers [13]. Other program activities could be implemented such as workshops on the bullying topic delivered within the program, conferences that may include sections and papers on this topic, anti-bullying campaigns developed by pre-service teachers, online discussion forums, etc.

For the implementation of these ideas, however, instructors willing to address the issue are needed [7], and a collective effort of those involved in the initial teacher education programs. Teacher educators should also learn about the best practices for preparing future teachers to deal with school bullying and find extra time to address bullying prevention [21]. With a loaded curriculum, this can become a real challenge. Therefore, a rethinking of the curriculum for initial training would be necessary to make more room for pressing and real problems in the world of education, such as bullying, poverty, tehnology, etc.

Providing training and support for pre-service teachers to tackle bullying is just one direction of action in the fight against such a complex phenomenon. Even given conditions of special attention to this issue in the initial training, once in school, these pre-service teachers need to be supported by the school's leadership team to strengthen their ability to prevent and manage student bullying behaviors [21]. Additional in-service training for teachers and school personnel is needed [23]. Teachers do not have to feel alone in managing the phenomenon. By involving the entire school community, principals, counselors, students and their parents and also other stakeholders in actions against bullying there are greater chances to ensure a safe and positive climate in schools and classrooms.

\section{Conclusions}

This paper has explored some opportunities for preparing future teachers to address school bullying based on an analysis of the curriculum offered by the psycho-pedagogical disciplines, which are part of the Romanian initial teacher education. By the analysis of the syllabi and by the consultation of teacher educators, we identified existing topics in the curriculum that can be explored from the perspective of developing competencies that future teachers need to identify, prevent and combat the phenomenon. To train these competencies, we suggested a series of learning activities (in the classroom and extended), without exhausting the possibilities for others to be added. The small number of respondents considered could be a limitation of the study. This disadvantage can be compensated by internal representativeness if we refer to the professional personnel involved in teaching the four disciplines within the department that offers the study program for future teachers.

An important advantage of the infusion approach proposed here is that these activities can be organized in the time slot allocated to the disciplines. The distribution of activities by disciplines helps avoid overlaps that may occur in the curriculum area, brings continuity over three years in approaching the topic, but does not exclude the possibilities for projects or interdisciplinary activities. Even if we mainly focused on the possibilities offered by the psycho-pedagogical disciplines, we also made suggestions regarding the other disciplines included in the study program. However, this is an area that could be further explored for new possibilities. Another direction could be related to the development of professional materials to support bullying instruction for teacher educators. Those working in different universities who train pre-service teachers on the same curriculum, but also those abroad working on a different type of curriculum, may find these suggestions useful, or can identify ideas that can be adapted or developed in different contexts. After all, bullying is an international problem, and preparing future teachers to prevent and combat it is a concern that transcends the configurations of any national curriculum. 


\section{References}

1. D. Olweus, Bullying at school: What we know and what we can do (Blackwell Publishing, Malden, 1993)

2. P. Downes, C. Cefai, [Online]. Available: https://nesetweb.eu/wpcontent/uploads/2019/06/NESET-II_Bullying-Report.pdf [Accessed 9 March 2021]

3. OECD, [Online]. Available: https://www.oecd.org/publications/pisa-2018-resultsvolume-iii-acd78851-en.htm [Accessed 10 March 2021]

4. C. Gradinaru, D. Stanculeanu, M. Manole, [Online]. Available: https://www.salvaticopiii.ro/sci-ro/files/10/10551dfa-f0b2-4cb0-a10308d811dc31a9.pdf [Accessed 23 February 2021]

5. W. Schulz, J. Ainley, J. Fraillon, B. Losito, G. Agrusti, T. Friedman, [Online]. Available: https://www.iea.nl/publications/study-reports/international-reports-ieastudies/becoming-citizens-changing-world [Accessed 26 April 2021]

6. OECD, [Online]. Available: https://www.oecd.org/education/talis-2018-resultsvolume-i-1d0bc92a-en.htm [Accessed 27 April 2021]

7. T. Beran, J. Soc. Sci., 8, 3, 43-49 (2005)

8. T. Begotti, M. Tirassa, D. Acquadro Maran, Int. J. Environ. Res. Public. Health, 15, 9, 1908 (2018)

9. J. L. Benítez, A. García-Berbén, M. Fernández-Cabezas, Rev. Electron. Investig. Psicoeduc. Psigopedag., 7, 1, 191-208. (2009)

10. H., Huang, Y. Liu, Y. Chen,. Front. Psychol., 9, 175. (2018)

11. Q. Li, Can. J. Learn. Technol., 34, 2 (2009)

12. P. Redmond, J. V. Lock, V. Smart, Comput. Educ., 119, 1-13 (2018)

13. P. J. Macaulay, L. R. Betts, J. Stiller, B. Kellezi, Educ. Stud., 46, 5, 590-606 (2020)

14. K. Rigby, Aust. J. Educ., 61, 1, 24-39 (2017)

15. UNESCO [Online]. Available: https://www.unicef.org/media/66496/file/Behind-the-Numbers.pdf [Accessed 6 March 2021]

16. L. Ciolan, Invatarea integrata: Fundamente pentru un curriculum transdisciplinar (Polirom, Iasi, 2008)

17. J. S., Renzulli, N., Waicunas, [Online]. Available: https://gifted.uconn.edu/wp-content/uploads/sites/961/2019/11/An_InfusionBased_Approach to Enriching the Standards-Driven_Curriculum.pdf [Accessed 22 March 2021]

18. Ministry of Education and Research, [Online]. Available: https://www.edu.ro/sites/default/files/_fi\%C8\%99iere/Legislatie/2020/OMEC_4343 2 020 norme $\% 20$ antibullying.pdf? [Accessed 20 January 2021]

19. W.R. Daggett, [Online]. Available: https://leadered.com/wp-content/uploads/Rigor-Relevance-Framework-White-Paper2016.pdf [Accessed 28 January 2021]

20. D.M. Cretu, MSE 2019, Designing rigorous and relevant learning experiences for future teachers, (Sibiu, Romania, 2019).

21. L. Lester, S. Waters, N. Pearce, B. Spears, S. Falconer, Aust. J. Teacher Educ., 43, 8, 30-45 (2018)

22. C. R., Johnson, [Online]. Available: https://www.bostonpublicschools.org/cms/lib/MA01906464/Centricity/Domain/204/e mbedding\%20bullying\%20prevention.pdf [Accessed 22 January 2021]

23. A. K. Gorsek, M.M. Cunningham, PURE Insights, 3, 6 (2014) 